\title{
Menuju Program Doktor ITB yang lebih solutif: Masukan untuk Panduan Program Doktor Kemitraan (PDK) ITB
}

\author{
Dasapta Erwin Irawan ${ }^{1}$ \\ ${ }^{1}$ Institut Teknologi Bandung
}

April 28, 2020

Terima kasih sebelumnya saya sampaikan karena telah diberi kesempatan untuk memberikan beberapa masukan ke dalam dokumen Naskah Akademik Panduan Penyelenggaraan Program Doktor Kemitraan (PDK) ITB. Berikut komentar saya yang terdiri dari komentar umum dan komentar khusus.

Walaupun utamanya ditujukan untuk ITB, tetapi komentar ini sepertinya relevan untuk Perguruan Tinggi lainnya yang juga akan menyelenggarakan program pendidikan riset berbasis kemitraan.

\section{Komentar umum}

Panduan ini sangat diperlukan sebagai rujukan penyelenggaraan PDK di ITB, karena selama ini Program Doktor (PD) di SPS ITB, lebih banyak dikelola atas inisiatif riset personal, baik dari personal mahasiswa, maupun dari personal dosen.

1. Selama ini, dosen lebih banyak mengembangkan pohon risetnya sendiri yang kemudian diterjemahkannya menjadi struktur penerimaan mahasiswa. Setelah itu, dosen umumnya akan pasif berharap akan ada mahasiswa yang mendaftar dan tertarik dengan program riset dosen ybs. Ide riset biasanya muncul setelah ada "call for proposal", kemudian mahasiswa mengikuti setelahnya. Dengan PDK, maka dosen secara aktif dapat mengembangkan pohon riset dengan cara non-konvensional (indikator non-konvensional).

2. Saya menangkap bahwa panduan ini disampaikan dengan intonasi (tone) lebih kuat untuk perguruan tinggi, tercermin sejak landasan penyusunannya (Bab 1) dengan penyebutan peringkat ITB dan yang sejenisnya. Semestinya sebagai program yang berbasis kemitraan, panduan ini perlu fokus kepada kondisi kemitraan riset ITB dengan berbagai pihak dan sejauh mana kemitraan itu dapat memberikan solusi untuk masalah di masyarakat. Saya sangat sadar itu sulit dilakukan, karena selama ini indikator keberhasilkan kemitraan belum pernah diarahkan ke dampak yang riil. Tapi selalu ada waktu untuk langkah pertama dan PDK adalah salah satunya.

3. Mengenai sumber pendanaan, menurut saya secara eksplisit perlu ditulis bahwa PDK dapat menerima pendanaan multi sumber. Ini penting karena sampai sekarang ada kesan pendanaan multi sumber akan berakhir dengan sangkaan pendanaan ganda (satu pengeluaran yang sama diajukan ke dua sumber dana berbeda). 


\section{Komentar spesifik}

1. Seperti telah disampaikan pada komentar umum, panduan ini disampaikan dengan intonasi (tone) lebih kuat untuk perguruan tinggi, tercermin sejak landasan penyusunannya (Bab 1) dengan penyebutan peringkat ITB dan yang sejenisnya. Selayaknya program kemitraan, semestinya panduan perlu juga menyinggung pentingnya kerjasama suatu lembaga dengan ITB dengan prinsip bersinergi, saling memperkuat posisi masing-masing, dan menyelesaikan masalah di masyarakat. Dalam Bab 1 memang disebut bahwa untuk meningkatkan kualitas riset diperlukan peningkatan kualitas pendidikan pasca sarjana, tetapi kembali lagi, motivasinya mestinya bukan untuk meningkatkan posisi peringkat ITB di level internasional. Disadari bahwa jumlah mahasiswa doktor memang menurun, tetapi hal tersebut bukan hal yang utama karena program ini adalah program kemitraan.

2. Pada bagian lain di Bab 1, mulai halaman 6, telah disampaikan berbagai pertimbangan kondisi pihak mitra, yang menurut saya tidak relevan dengan posisi peringkat ITB yang dibahas pada hal 1. Semestinya sejak awal panduan membahas kondisi kemitraan pada proses pendidikan doktor yang selama ini telah dilakukan. Berkaitan dengan hasil kuesioner yang membahas proporsi terbesar latar belakang program mahasiswa doktor adalah dosen dari perguruan tinggi, ini dapat digunakan sebagai salah satu latar belakang kuat untuk menyelenggarakan PDK. Konteks ini sangat kuat untuk diangkat.

3. Hasil kuesioner berikutnya yang membahas tentang proporsi lulus dan DO masing-masing untuk kelompok akademisi dan non-akademisi juga bisa diangkat menjadi fokus. Salah satu penyebabnya mungkin adalah riset mahasiswa berawal dari inisiatif riset yang parsial dengan sumber pendanaan yang belum terencana dengan baik. Justru masalah ini yang bisa menjadi dasar penyusunan PDK, khususnya untuk meningkatkan kualitas sumber daya manusia non-akademisi.

4. Melanjutkan komentar untuk bagian lainnya, tujuan PDK (hal 8) perlu dihubungkan dengan cara pengukuran keberhasilannya. Tujuan fokal untuk meningkatkan hubungan (link and match) tidak akan dapat diukur bila ITB menggunakan indikator yang lebih fokus kepada peningkatan peringkat ITB, yaitu menghitung jumlah makalah (hal $20 \mathrm{dst}$ ). Hal ini penting terutama dengan penetapan PDK sebagai program doktor non-konvensional (hal 8) sebagai salah satu keunikan. Meninjau keunikan lainnya, saya melihat PDK ini bila dikelola dengan cara yang berbeda (dengan PDR/pendidikan doktor reguler), akan memberikan nuansa/warna lain kepada hasil riset ITB. Catatan ini juga relevan untuk mencapai tujuan yang tercantum dalam paragraf akhir hal 10 ("... memimpin pengembangan perusahaan/institusi di mana ia bekerja.") juga relevansi PDK dengan Renstra ITB 2016-2020 (hal 11).

5. Dalam Bab 2 hal 14 telah disampaikan konsep pengembangan riset industri yang menjadi esensi dari PDK. Ada satu masalah dengan riset industri yang nantinya pasti akan sangat dihubungkan dengan paten dan keuntungan. Paten akan berhubungan dengan pembatasan akses terhadap inovasi, sedangkan keuntungan akan menjadi motif yang tidak mendorong pendidikan (catatan: dalam grafik hal 14, sudah tertera "market driven"). Untuk itu keseimbangan konsep riset industri dan non-industri perlu dijaga, karena kemitraan akan datang tidak hanya dari industri komersial tetapi juga dari inisiatifinisiatif nir laba yang diprakarsai lembaga pemerintah maupun lembaga non-pemerintah (misal: LSM). Saya masih melihat ada kesempatan lain PDK sebagai agen perubahan bagi masyarakat/bangsa dengan mengakomodasi riset non-industri, yang menghasilkan inovasi dengan akses terbuka tanpa harus kehilangan Hak Cipta yang akan dimiliki oleh peneliti (mahasiswa, pembimbing, lembaga asal mahasiswa dan ITB tentunya). Menurut saya mengembangan inovasi terbuka justru akan mendorong nilai-nilai luhur yang diyakini oleh ITB selama ini, seperti juga tercantum dalam kompetensi utama pendidikan doktor sesuai KKNI, "memecahkan masalah rekayasa dan teknologi di dalam bidang keilmuannya melalui pendekatan inter, multi transdisipliner..." (hal $15 \mathrm{dst}$ ). 


\section{Kesimpulan}

PDK disusun dengan kepentingan ITB yang lebih dominan. Latar belakang motif meningkatkan peringkat perlu dikesampingkan, menurut saya, untuk mencapai ITB yang lebih baik, lebih beragam, dan lebih mampu menjawab masalah di masyarakat. Untuk itu, perbaikan perlu dilakukan pada bab latar belakang dan indikator kinerja, agar memenuhi kriteria sebagai pendidikan doktor yang non-konvensional. Semoga PDK dapat dijalankan dengan baik.

Terima kasih sekali lagi atas kesempatan yang diberikan untuk memberikan komentar atas dokumen panduan. 